\title{
OS FESTEJOS DE ENTRUDO NO SÉCULO XIX
}

Patrícia Vargas Lopes de Araujo (UFV)

Este artigo procura problematizar os festejos de entrudo, buscando compreender a multiplicidade de sentidos das manifestações carnavalescas, a partir das narrativas de viagem produzidas sobre o Brasil, no século XIX, pelos viajantes estrangeiros. Festejo com costumes curiosos e brincadeiras consideradas pouco elegantes, o entrudo caracteriza-se por ser prática cultural multifacetada, em torno da qual se construíam significados do viver social e se projetavam simbolicamente as representações de mundo.

ENTRUDO, VIAJANTES, SÉCULO XIX. 
O entrudo foi a primeira manifestação carnavalesca no Brasil. Caracterizava-se como conjunto de folguedos ligados a práticas que englobavam uma série de brincadeiras, nas quais predominavam as que envolviam a utilização de água. Não é possível estabelecer com certeza data ou momento em que entrou no cenário brasileiro. Contudo, vários autores apontam o início do século XVII como época em que o entrudo passa a integrar o calendário festivo colonial (MORAES, 1958; QUEIROZ, 1987; CUNHA, 1996).

É importante chamar atenção para a especificidade do entrudo, muitas vezes confundido com carnaval, como se um e outro fossem a mesma coisa. A palavra mais frequente na documentação é, sem dúvida, entrudo e muito raramente carnaval para designar os dias de folguedo que antecediam a Quaresma.

No Diccionario da Lingua Portugueza, publicado por Antonio de Morais Silva em 1813 , encontra-se algo notável a esse respeito e esclarece que o que se brincava era o entrudo. No verbete Carnaval lê-se: "O tempo do Intrudo, as festas, regozijos, que então se fazem" (p. 348). E o que é entrudo? "são os três dias imediatamente precedentes à Quaresma, nos quais é uso entre nós divertir-se o povo com se molhar, empoar, fazer peças, e outras brincadeiras e banquetear-se..." (p. 718).

Muitos viajantes estrangeiros (aqui tomados no sentido mais geral do termo, ou seja, aqueles que se deslocam de uma parte a outra, movidos por interesses variegados) que passaram pelo Brasil durante o século XIX fizeram inúmeros registros sobre o modo "curioso" como os brasileiros se divertiam nos dias antes da Quarta-feira de Cinzas. Os relatos normalmente recaem sobre o tumulto e a alegria dos dias de entrudo. Os festejos em todo o Brasil não lembravam, segundo esses viajantes, nem os bailes, nem as mascaradas europeias. Tais narrativas "apontam modos como as culturas se olham e olham as outras, como estabelecem igualdades e desigualdades, como imaginam semelhanças e diferenças, como conformam o mesmo e o outro" (BELUZZo, 1996, p. 10).

Diferentemente dos séculos anteriores, o XIX conhecerá grande afluxo de estrangeiros para terras brasileiras. Nesse período, há vivo interesse em conhecer e desvendar culturas e países diferentes. O culto "ao outro" exercia grande fascínio entre os intelectuais europeus, e os "países exóticos, como eram então chamadas as colônias, exerciam uma enorme atração" (LEITE, 1997, p. 60).

O Brasil era, como muitos outros países e colônias, procurado por colocar em questão o estranhamento e o desconhecido perante o viajante. Os temas relatados tiveram frequentemente como critério a escolha de fatos considerados "exóticos". Sempre que possível eles procuraram evidenciar as diferenças entre seus países de origem e o Brasil.

Ao registrar essa informação, o viajante construiu e repassou um tipo de imagem e impressão, colocando-se ao mesmo tempo como tradutor/intérprete dos grupos existentes, de seus significados. A divulgação da presença desse grupo para o público leitor europeu tinha como objetivo principal revelar o "outro", no que este possuía de desconhecido, novo, diferente. A visão que foi possível formar a partir da experiência passou pelo contato direto com os po- 
vos colonizados, ou seja, com o que foi, então, identificado como sendo o outro, a população local (LEITE, 1997, p. 60).

Dessa maneira, é fácil perceber que as relações estabelecidas entre viajantes e brasileiros, e o que estava por ser desvendado, eram desiguais. Na "qualidade de estrangeiro", esse viajante transformava-se em observador privilegiado e atento dos "aspectos, incoerências e contradições da vida cotidiana que os habitantes, ao dá-la como natural e permanente, encontravam-se incapazes de perceber" (p. 9). Por outro lado, o viajante chegava ao Brasil portador de muitos preconceitos, munido da ideia de ser a imagem da "civilização" diante de um "povo atrasado". Tal postura agravava-se quando se via frente a obstáculos linguísticos, culturais e econômicos. Na tentativa de compreensão dos grupos visitados, foram esses observadores responsáveis por estereótipos que vigoraram por todo século XIX.

O europeu do século XIX viajava para encontrar o outro, mas nesse percurso acaba por reafirmar os valores de sua própria cultura. Para esses homens, as viagens constituíam "experiência central da vivência da história e para a pedagogia de todo cidadão esclarecido" (GUIMARÃES, 2000). O editor da Bibliothèque Universelle des Voyages, publicada a partir de 1833, cuja finalidade era ser uma enciclopédia de todas as viagens realizadas no decorrer da história, afirmava:

As viagens são a escola do homem, ele não dá um passo sem aumentar os seus conhecimentos e ver recuar diante de si o horizonte. À medida que avança, seja através de observações próprias, seja lendo os relatos de outros, ele perde um preconceito, desenvolve o espírito, apura o gosto, aumenta a sua razão acostumando-se ao altruísmo. E tanto por necessidade quanto por justiça em relação à humanidade, sente-se a cada vez impelido a se tornar melhor, dizendo a si mesmo segundo o filósofo inglês Tolland: o mundo é a minha pátria, e os homens são meus irmãos (apud GUIMARÃES, 2000).

Apesar da posição "humanista" indicada pelo editor da Bibliothèque, a apreciação efetuada pelos viajantes sobre diferentes partes do mundo, e em particular sobre a América, era marcada ou perpassada pelo fato de os europeus, vindos de países "civilizados", constituírem uma autorrepresentação. Por outro lado, porém, ao se deslocar por toda parte, contribuíam, como aponta Mary Louise Pratt (1999), para a formação de nova consciência, de caráter mais universal. Esses europeus partiam para suas viagens munidos de olhar instrumentalizado e informados pelas perspectivas teóricas em voga na Europa, bem como pelas concepções de progresso, e dessa maneira adotavam na maior parte das vezes postura etnocêntrica.

A utilização dos relatos desses "estrangeiros" sobre o entrudo não deve perder de vista que seus registros são portadores de valores, preconceitos, assim como de visão idealizada sobre os trópicos, muito diferente da realidade a ser explorada. É necessário "desconfiar das pistas viciadas que esses viajantes possam ter deixado" (sCHWARCZ, 1999, p. 12), mas, se a incompreensão e o estranhamento diante de uma cultura diversa da sua os fizeram descaracterizar em muitas situações os costumes brasileiros, tornaram-se, por 
outro lado, extremamente detalhistas em suas descrições, fazendo de seus relatos preciosa fonte de informação.

Ainda assim, entretanto, são necessários certos cuidados, pois os mesmos aspectos que fazem de seus relatos fonte preciosa apresentam também seus limites. Dessa forma, a busca de sinais de alteridade faz com que a princípio, por desconhecimento da outra cultura, o viajante interprete mal as mensagens que recebe e lhes atribua outros sentidos. O século XIX seria marcado por confrontos produzidos, entre outras questões, pela diferença de padrões estéticos. Foi o momento também, é preciso não esquecer, de afirmação do Brasil como nação.

Membros muitas vezes da aristocracia de seus países e frequentemente intelectuais, esses viajantes tornavam-se elos importantes na circulação de informações e de notícias entre o Novo Mundo e o velho, bem como intermediários entre os lugares "exóticos" e os museus e jardins botânicos de diversos países europeus. Viajavam munidos da crença do progresso, da ciência, do bem-estar dos povos e da glória da nação, sendo-lhes imprescindível, desse modo, a formação científica.

Outro aspecto a ser ressaltado nas narrativas dos viajantes é a presença de descrições de caráter pictórico, como detalhes, tons, unidade cromática, indicações de coloração, dobras e volumes. A presença desses elementos aponta para cenas construídas com a finalidade de efeitos plásticos. Tal questão indica a existência de um olhar de paisagista por parte desses estrangeiros. $E$, mais, isso seria indicativo de uma formação intelectual que demonstra o conhecimento de conceitos e padrões estéticos que conformariam o ato de composição artística, seja a pintura ou a escrita.

Os festejos de entrudo eram, aos olhos estrangeiros, um tipo de costume muito diferente. Segundo John Mawe (1978, p. 73), no Brasil entre 1807 e 1810, consistia em uso muito desagradável para estrangeiros. Anos mais tarde, Ferdinand Denis, escrevendo entre 1816 e 1831, se pronuncia sobre essa questão e evidencia o espanto que o festejo causava nos estrangeiros:

Nem o carnaval de Veneza, que tanto tem perdido de seus esplendores, nem as mascaradas moribundas que se veem ainda em Paris, poderiam oferecer ideia exata do tumulto, da loucura ardente que reina, durante os dias de entrudo, não só no Rio de Janeiro, mas em todas as cidades do Brasil (DENIS, 1978, p. 142).

Denis descreve os festejos do entrudo em seu livro utilizando-se do relato de outro viajante, Robert Walsh, que esteve no Brasil em 1828 e 1829, integrando como capelão a comitiva de Lord Strangford. Walsh relata descrições sobre a natureza, cidades e costumes observados no Brasil. Além disso, registra também notícias sobre a história do país até o momento da Independência, fazendo desenhos e mapas da Cidade do Rio de Janeiro e da Província de Minas Gerais. Sobre o entrudo, também ele enfatiza o exotismo e a singularidade das brincadeiras praticadas no Brasil.

O costume era considerado tão extraordinariamente diferente pelos estrangeiros, que se tornava objeto de anotações e longos comentários sobre esse aspecto da vida cul- 
tural brasileira em seus diários/relatos de viagem. A minúcia nas descrições faz de seus relatos fontes imprescindíveis no fornecimento de informações sobre as práticas do entrudo e de uma gama de manifestações sociais e culturais, ao longo de todo o século XIX.

A esse respeito, também escreveu Jean-Baptiste Debret (1949, tomo 1, p. 220):

O Carnaval no Rio e em todas as províncias do Brasil não lembra (...) nem os bailes nem os cordões barulhentos de mascarados que, na Europa, comparecem a pé ou de carro nas ruas mais frequentadas (...). O limão de cheiro, único objeto dos divertimentos do Carnaval, é um simulacro de laranja, frágil invólucro de cera de um quarto de linha de espessura e cuja transparência permite ver o volume de água que contém. A cor varia do branco ao vermelho e do amarelo ao verde.

A ideia da singularidade dos festejos do entrudo anunciada pelos viajantes é compartilhada por cronistas brasileiros, quando procuravam demarcar as diferenças existentes entre a forma de brincar dos brasileiros - por extensão a dos portugueses - da dos italianos e franceses, sobretudo. Esse olhar "nacional" distinguia-se, no entanto, porque não revelava estranheza, mas reconhecimento, uma sensação de fazer parte desse costume.

Predominam no entrudo as brincadeiras de jogar água e molhar as pessoas. No século XIX foram incorporadas à prática os limões de cheiro ou laranjas de cheiro considerados forma mais refinada de jogar. Contudo, o refinamento terminava quando se esgotava a provisão de limões e o festejo transformava-se em verdadeiros combates de água (Figura 1).

A preparação para os festejos do entrudo iniciava-se com grande antecedência, pois era preciso "fabricar" os limões. Uma verdadeira "indústria familiar" ocupava-se dos

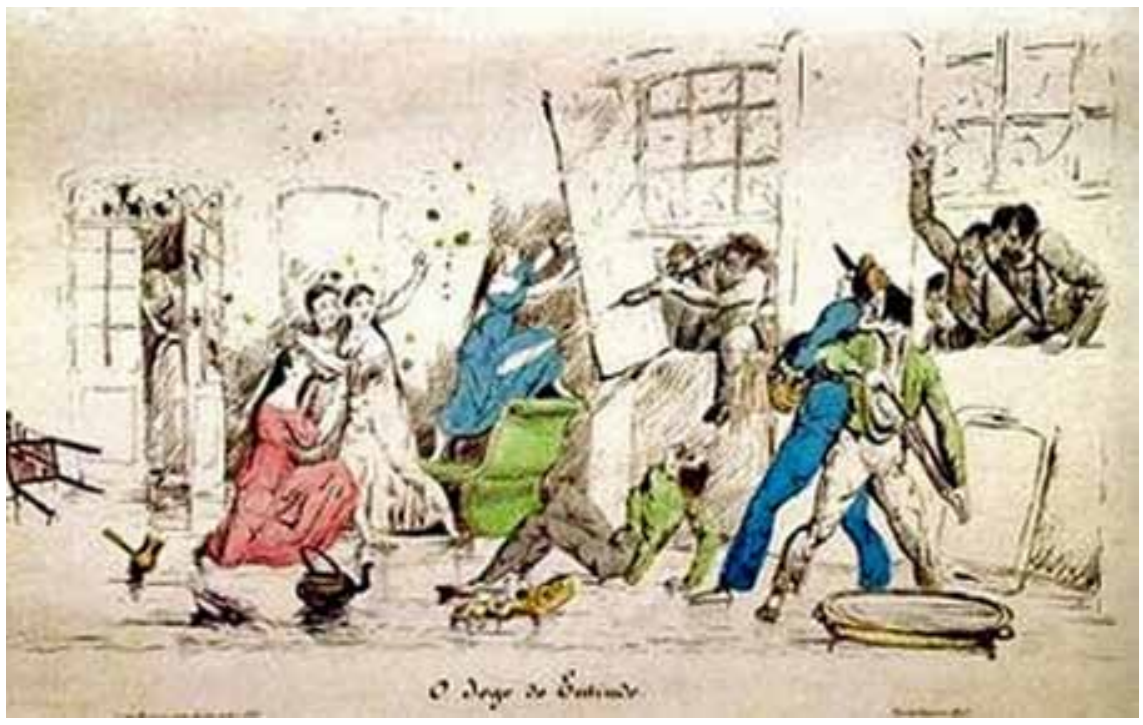

Figura 1: $O$ jogo de entrudo (1840), litografia de Rafael Mendes de Carvalho 
preparativos para os dias de entrudo. Esses momentos de encontro para a fabricação dos limões revelavam-se propícios à solidificação dos laços familiares, pois a festa motiva e reforça as práticas comunitárias (HEERS, 1987, p. 14). A participação masculina, entretanto, não era tão ativa; a preponderância dos preparativos e do fabrico dos limões e do festejo cabia aos elementos femininos do grupo familiar.

A fabricação dos limões de cheiro significava ainda um meio de renda provisório e extra para as famílias, pois, além de produzirem para si, aceitavam encomendas desses projéteis. Os limões de cheiro e também outros instrumentos como as seringas (feitas de folhas de flandes ou bambu), polvilhos e farinhas eram expostos à venda nas ruas, nas lojas, diante das casas ou em tabuleiros carregados por escravos pela cidade. A farinha, lançada sobre um só indivíduo, era normalmente jogada sobre os negros e mulatos, provocando muitos risos por sua aparência.

Ina von Binzer, pseudônimo de Ulla von Eck, que veio ao Brasil em 1881, permanecendo até 1884, sobre essa questão registrou que todos os anos repetia-se "a mesma coisa", a despeito das proibições. "Nas esquinas até as pretas oferecem à venda enormes bandejas cheias de laranjinhas" (BINZER, 1956, p. 72). Esse "até" da viajante alerta para o fato de haver comércio de certa forma generalizado desses artigos.

"Não era [com] uma chuva de confeitos, que as pessoas se saudavam nos dias de entrudo, mas com chuveiros de laranjas e ovos", registraram os missionários americanos James Cooley Fletcher e Daniel P. Kidder (1941). Esses artigos, preparados com antecedência em grandes quantidades, eram bastante resistentes de maneira a poder ser lançados "a grande distância, mas, no momento do choque, fazia[m]-se em pedaços, espaIhando água por onde caísse[m]" (p. 164-165).

O que chama atenção de início na brincadeira do entrudo é o fato de que se trata de festejo comemorado particularmente com amigos ou conhecidos. Os jogos ocorriam entre famílias ou entre pessoas que se conheciam ou mantinham laços de amizade. No Diccionario da Lingua Portugueza, já citado, brincar esse folguedo significava "entrudar com amigos", isto é, brincar com pessoas que mantinham laços de parentesco ou faziam parte do círculo de conhecidos.

Os jogos de entrudo não se confinavam a quatro paredes e ocorriam tanto dentro das casas como fora delas. Não são poucos os relatos que deixam entrever que também os desconhecidos eram "atacados" e tornavam-se "vítimas" em potencial, principalmente se estivessem pelas ruas e praças. Nesses casos, os ataques poderiam vir dos sobrados ou de vários pontos da rua, de onde não se suspeitaria que algo pudesse acontecer.

Há uma linha muito sutil estabelecendo e demarcando o limite entre brincar em família e com conhecidos, e o brincar na rua. A rua, ao que tudo indica, revelava-se território "livre". A movimentação e a circulação entre o espaço privado e o público parecem menores entre as famílias senhoriais, que, possivelmente mais cuidadosas e preocupadas com as etiquetas sociais, "entrudavam-se" preferencialmente no interior das casas e dos sobrados, postadas nas sacadas, com os familiares, amigos ou conhecidos. 
A esse respeito é elucidativo o que informa Ferdinand Denis (1978, p. 142):

Durante este tempo de folia, um amigo me havia conduzido a fazer uma visita; desde as primeiras saudações, fomos acolhidos por uma chuva de ovos amarelos e verdes, que as jovens e as belas mulheres da família nos arremessavam impiedosamente ao rosto. Fomos então convidados a nos debruçar nos balcões das janelas, e dali vimos todos os que enchiam a ruas, fugindo de algum projétil ou espreitando a aproximação de alguma vítima. Quando qualquer um aparecia, era no mesmo instante atacado de todas as direções e inundado de torrentes de água em um minuto; seu chapéu se tornasse então alvo de milhares de ovos amarelos e verdes.

As informações dos viajantes estrangeiros são a esse respeito preciosas, já que mantiveram contato, principalmente, com pessoas e famílias de posição mais elevada na hierarquia social. Thomas Ewbank, que esteve no Brasil em 1846, descrevendo o entrudo passado no Rio de Janeiro, informa sobre os folguedos ocorridos dentro de casa, iniciados, para seu espanto, logo pela manhã.

O relato de Ewbank é valioso porque, ao ser generoso em suas informações, permite formarmos imagens e compreendermos um pouco como acontecia a brincadeira, no interior de uma casa, e possivelmente de uma família "bem situada" social e economicamente na sociedade. Inicia dizendo que, enquanto tomava seu café da manhã,

S. passou por trás da cadeira de J. e, para grande espanto meu, esvaziou um par de cilindros sobre a cabeça e os ombros do mesmo. A operação foi realizada tão silenciosamente e o pó caiu tão leve que J. não percebeu o acontecido, senão quando um punhado de pó foi-lhe aplicado ao rosto e às orelhas. Cuspiu, ergueu-se e, meio cego, foi saudado com esguichos de líquidos de uma garrafa de água da colônia de gargalo cumprido. Meio encolerizado e entre muitas risadas, efetuou uma rápida retirada, vestiu-se e saiu para a cidade.

Enquanto perguntava a mim mesmo o que significaria tal coisa, senti caírem de minha testa uma ou duas partículas. Erguendo a mão verifiquei que meus cabelos também haviam sido cobertos de pó. Meus gritos provocaram gritaria geral. Levantei-me para fugir, mas isso fora previsto e a única porta através da qual podia escapar encontrava-se fechada à chave. Cercado agora por um exército de inimigos femininos, esquivei-me e corri até me sentir quase exausto, tentando fugir de incessantes ataques de amido e água (EWBANK, 1979, p. 81).

A esse respeito é interessante, por exemplo, a pintura de Augustus Earle ${ }^{1}$ que retratou cena cujos atores principais são homens, de idades variadas e três mulheres, que se destacam na composição, alvejando um senhor, defronte ao qual se senta um monsenhor, com a batina levantada, mostrando suas meias rosadas (Figura 2). Vemos ainda na cena, limões de cheiro em pro1. Pintura publicada pela primeira vez em 1965 em A muito leal e histórica cidade de São Sebastião do Rio de Janeiro pelo pesquisador Gilberto Ferrez, responsável pela formação de uma das mais importantes coleções privadas de fotografia brasileira do século XIX.

fusão em bandejas, algumas delas carregadas por escravos, bacias d'água, esguichos e uma gamela cheia de farinha. A brincadeira estende-se de janela a janela, incluindo pessoas de outra casa, que vigiam a casa da frente, jogando em di- 


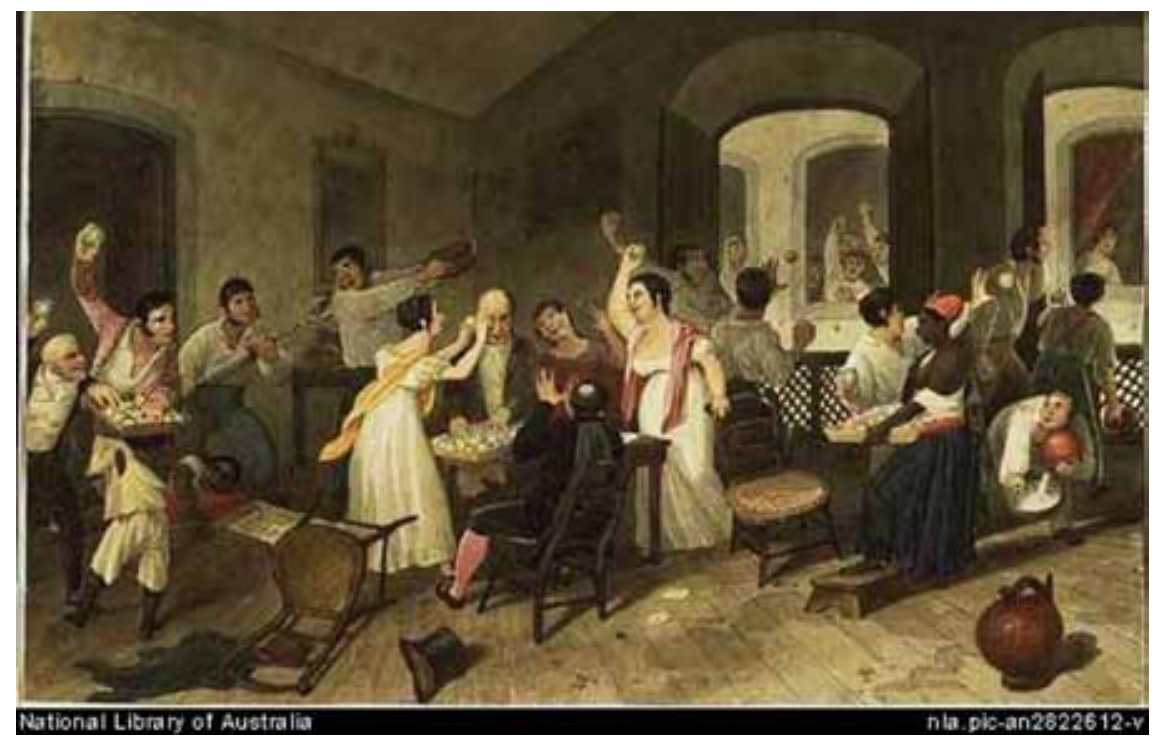

Figura 2: Entrudo. Games at Rio during Carnival (1822-1823), Augustus Earle Disponível em nla.gov.au/nla.pic-an2822612

reção a esta os projéteis. Diferentemente da pintura de Debret, os escravos aqui são coadjuvantes.

Earle retrata um aposento assobradado de frente para a rua, com móveis dispostos pelo ambiente, retrato e espelho com molduras douradas pendurados nas paredes. A treliça do balcão é indício dos muxarabis e gelosias, de origem árabe, que serviam para suavizar a claridade no interior dos aposentos e preservar a intimidade da casa, bem como para "ver sem ser visto", de modo que seriam proibidos a partir de 1808 e substituídos por janelas de vidro.

A não distinção entre a casa e a rua, a rua quase como um prolongamento da casa, parece maior entre as famílias e pessoas de camadas sociais intermediárias e mais pobres. Nas casas de "gente pobre" a brincadeira acontecia com "menos apetrechos, menos etiqueta, mais desregramento" (CUNHA, 1996, p. 100) e grandes banhos eram dados nas pessoas de convivência ou nos "incautos" que eram agarrados.

$\mathrm{Na}$ rua, os homens revelavam-se os principais personagens das brincadeiras. $\mathrm{Na}$ sociedade brasileira do século XIX, a rua parece representar um espaço predominantemente masculino, em contraposição ao espaço privado da casa, onde reinavam as mulheres. Na rua, os homens sentiam-se mais à vontade para espreitar seus conhecidos, escondendo-se em lojas ou atrás das portas com seringas e imensas gamelas de água para moIhar "uns aos outros sem descanso", de maneira que a rua ficava "por fim inundada" (DENIS, 1978, p. 143). Era também espaço em que os negros podiam brincar o entrudo. 
As mulheres brasileiras, muitas vezes mencionadas pelos viajantes estrangeiros como recatadas, pareciam libertar-se provisoriamente das convenções sociais durante o entrudo. Henry Koster, participando do divertimento, observa:

Conseguimos aqui ver as senhoras da casa. Por toda parte eram rigorosamente guardadas e naturalmente reservadas para que tomassem parte entre nós. Os rapazes que tinham relações com a família puderam interessá-las na brincadeira, e as senhoras e as escravas participavam valentemente da luta (KOSTER, 1972, p. 281).

Também a Denis (1978, p. 143) parecia surpreendente a mudança operada durante esses dias de folia. Segundo esse estrangeiro, elas mudavam "completamente" de caráter nessa época do ano, de forma que a gravidade e a timidez, que ele Ihes supunha naturais, se "abafam em risos".

Muito frequentemente eram elas que começavam os combates. Durante os dias de entrudo, as aproximações entre homens e mulheres se faziam com maior facilidade. As brincadeiras permitiam que as rígidas barreiras impostas pelo controle social, sobretudo as morais, ficassem mais frágeis, possibilitando a mulheres e homens maior contato.

0 jogo de entrudo realizava-se preferencialmente entre elementos de sexo oposto com a iniciativa partindo das mulheres. Os homens pareciam mais zelosos das etiquetas e códigos sociais, mas revidavam e, uma vez na brincadeira, participavam com tanta animação quanto as mulheres. "Um homem", afirma Koster (1972, p. 281), "dizia aos que brincavam que não o molhassem porque estava adoentado. Não percebia, entretanto, que não observava para os outros a indulgência solicitada para ele mesmo". E continua seu relato, "[u]m do grupo, vendo isto, atacou-o com um colherão de prata cheio de água (...) As mulheres, especialmente, o atacaram em regra".

Segundo John Mawe (1978, p. 73), porém, era considerado de grande impropriedade os homens se alvejarem com limões de cheiro e, por extensão, atirarem água uns nos outros. Entretanto, por ser considerado impróprio os homens alvejarem-se, eles se utilizavam muitas vezes de subterfúgios para brincar e molhar as pessoas.

As mulheres, entretanto, mais à vontade nesses dias, brincavam entre elas tranquilamente e, segundo Debret (1949, tomo 1, p. 221), orgulhavam-se do grande número de vestidos que molhavam nesses dias como demonstração de sua habilidade.

Há singular dinâmica no desenrolar dos jogos de entrudo. Em casa e no espaço privado, prevalecia a brincadeira entre homens e mulheres, entre familiares e conhecidos; das sacadas e janelas para rua, envolvendo desconhecidos; e, finalmente, na rua, o combate predominantemente entre homens, conhecidos ou não, com ataques aos que se aventuravam ou necessitavam sair de casa nesses dias. Apesar disso, o entrudo não era festa desprovida de hierarquização e regras. Sob a aparência de prática generalizada e indiscriminada, é possível identificar limites e a existência de diferenciações na maneira de festejar. Mesmo sendo possível notar a espontaneidade com que se realizava a festa, ou mudança nos papéis sexuais, ela possuía regras e aspectos evidenciadores de controle social, e, de certa forma, traduzia as hierarquias e posições sociais vigentes na sociedade. 


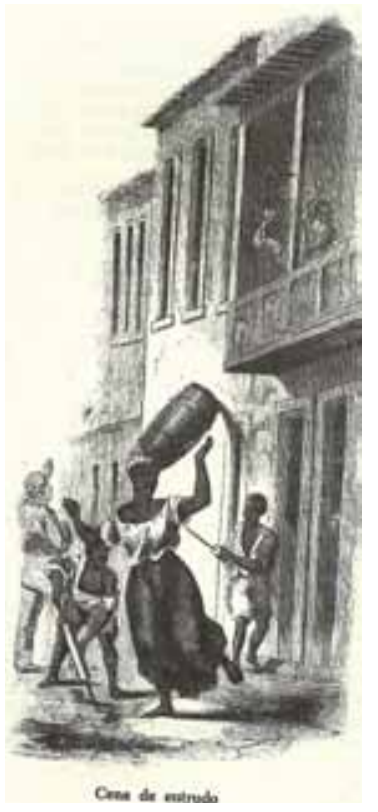

Figura 3: Cena de entrudo, Thomas Ewbank, Vida no Brasil
A festa é momento singular no qual a percepção do tempo se reveste de colorido e ganha novos significados. Desse tempo festivo, contudo, não se elimina completamente o mundo do dia a dia, do qual fazem parte a diversidade e as diferenças. $O$ tempo festivo não deixa de expressar os valores e as concepções de vida e de sociedade vigentes o ano todo e, mais do que isso, as mantém.

A esse respeito é interessante mencionar a imagem que ilustra o livro de Thomas Ewbank, Vida no Brasil, reproduzindo cena em que os negros brincam entre si na rua, e da sacada de um sobrado duas jovens neles atiram projéteis (Figura 3). Também Daniel Kidder (1951, p. 116), no Brasil entre 1837 e 1840, a esse respeito assim se referiu: "Homens e mulheres põem-se nas sacadas de onde brincam entre si e com os transeuntes".

Esse tipo de situação sugere a presença de noção de hierarquização da vida social durante os festejos. Pessoas ou grupos pertencentes à camada considerada socialmente superior brincavam entre si, com conhecidos e permitiam-se atirar água e limões de cheiro em desconhecidos que passassem pela rua ou pessoas supostas inferiores na escala social. No entanto, é preciso matizar essa questão.

Embora partindo do pressuposto de que os festejos de entrudo ocorrem entrelaçados à experiência social e ao cotidiano, é necessário, por outro lado, estar alerta também às sutis ameaças que os festejos potencializam.

Nesse contexto, qual seria a situação dos escravos? Além de venderem os limões, eles pareciam em determinadas situações participar como coadjuvantes nos festejos. Além da realização das tarefas rotineiras - ajudar no fabrico dos limões de cheiro e no preparo de refeições - cabia-lhes desempenhar o papel de auxiliares dos foliões brancos. Alguns jovens, "moços e ricos", faziam-se acompanhar por "negrinhos que trazem um completo sortimento" (BINZER, 1956, p. 72) de limões e bisnagas em grandes cestos para que seus donos possam brincar.

Os proprietários de escravos podiam sair à rua acompanhados de pretos ou moleques, carregando tabuleiros de limões de entrudo ou grandes seringas de folhas de flandes ou de bambu. Os negros podiam ainda servir de "vítimas" para as brincadeiras 


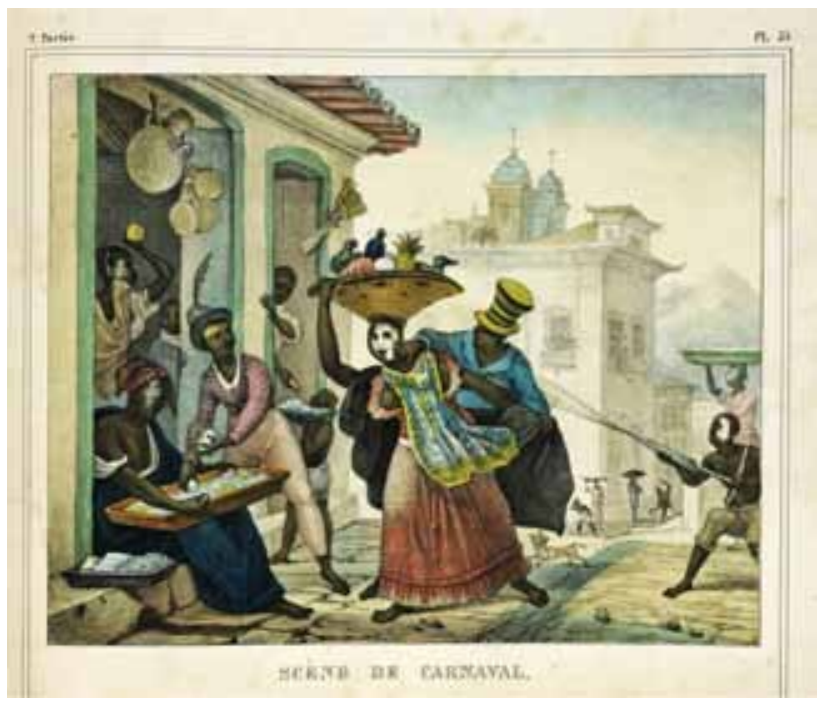

Figura 4: Scène de Carnaval, Jean-Baptiste Debret, Viagem Pitoresca e Histórica ao Brasil

de jovens brancos, já que não seria muito conveniente que escravos atirassem água ou limões sobre qualquer pessoa que não fosse de sua cor (EWBANK, 1979, p. 84). Um negro entrudar um senhor era considerado "ousadia" e desrespeito imperdoável (EWBANK, 1979; BINZER, 1956). Mantendo "respeito" por seus senhores e outros brancos, os jovens negros "raramente" molestavam "qualquer pessoa que não [fosse] de sua cor", observou Ewbank (1979, p. 84). As pessoas brancas, porém, não sentiam o menor constrangimento em "atacá-los".

Cabe indagar, entretanto, se havia de fato respeito a essas proposições sociais. Será que as pessoas ou grupos de pessoas pertencentes a estratos sociais descendentes obedeciam a essas regras ou criavam formas de desafiá-las?

Obviamente, os escravos encontravam suas próprias maneiras de brincar. Embora sua liberdade fosse cerceada, eles criavam espaços de participação no interior da sociedade. Entre uma tarefa e outra, logo ao amanhecer ou depois do anoitecer, era possível encontrá-los brincando próximo aos chafarizes e fontes aonde iam buscar água para seus senhores.

Os festejos iniciavam-se "no domingo às cinco da manhã entre alegres manifestações de negros, já espalhados pela rua (...) embora sempre respeitosos para com os brancos, reúnem-se depois do jantar nas praias e nas praças, em torno dos chafarizes, a fim de se inundarem de água" (DEBRET, 1949, p. 219). A rua, parece, tornava-se espaço privilegiado para o desenrolar das brincadeiras entre os negros. O desenho intitulado Cena de carnaval, de Jean-Baptiste Debret, permite vislumbrar entrudo de rua, cujos personagens centrais são os negros brincando defronte a um mercado (Figura 4).

Vê-se uma negra carregando cesto na cabeça contendo alimentos, rodeada por outros negros. Dois deles lançam-se sobre ela, um adulto lhe suja o rosto, e um menino lhe joga água com a seringa. Sentada à porta do mercado está outra mulher, com um 
tabuleiro de limões de cheiro no colo e um ao lado com prováveis pacotes de polvilho ou outro pó, também com o rosto já sujo, evidência de sua participação nos folguedos. Em sua mão vemos o dinheiro que segura, resultado de suas vendas. A seu lado, um jovem apanha os limões do tabuleiro com o intuito de atirá-los na negra do tabuleiro de alimentos.

Nas portas do mercado, vê-se um homem, também negro, comprando um pacote de polvilho de um menino. No interior do mercado há ainda duas pessoas, uma muIher com um limão pronto para ser lançado e um homem "de tocaia". Nesse quadro, os negros ocupam o primeiro plano da cena, indicando que a rua e o espaço público tornavam-se lugar de significação para eles. Um lugar em que se podiam manifestar.

A rua, espaço destinado à venda dos limões e outros produtos para o entrudo, era "ressignificada", ganhava novo sentido. Não se restringia mais ao espaço com a finalidade tradicional; tornava-se um lugar de festejar. A transformação dos espaços em lugares está essencialmente vinculada a seu sentido coletivo, pois "como o espaço não é para o vivido um simples quadro e como o sujeito vive através de um modo de apropriação, a atividade prática vai mudando constantemente o espaço e os seus significados", acrescentando "novos valores" (CARLOS, 1996, p. 74).

Nos festejos do entrudo as brincadeiras parecem desenvolver-se em consonância com regras próprias ao jogo e também de acordo com posições sociais. O reino da total e mais completa igualdade entre todos, na realidade, não existe. Ser um tempo especial não implica ser isento ou indiferente às hierarquias, ao poder ou à segmentação social. A ausência de hierarquias e o estabelecimento da igualdade entre todos pertence a uma dimensão utópica, mais do que ao plano da realidade e do mundo real. As diferenças do dia a dia não se apagam durante os festejos, embora possam apresentar-se mais suavizadas.

Contestando a ideia da festa transformada de permissividade em licenciosidade e também os estudos que partem dessa perspectiva, Maria Isaura Pereira de Queiroz alerta para o fato de a ordem social não ser subvertida durante os dias de entrudo e sobre a conservação do status das camadas abastadas. Da mesma forma, ela afirma, não existe oposição ou incompatibilidade entre festa e cotidiano, pois tanto uma quanto outro se apoiam nas mesmas estruturas. "Nascendo em uma determinada sociedade, a festa não entra em contradição com ela; ambas pertencem à mesma ordem das coisas, que é a ordem do vivido" (QUEIROZ, 1994, p. 220).

Certos limites eram traçados e delimitados no interior do espaço festivo. A festa pressupunha, ainda que frágeis, permissão e aquiescência. As pessoas deviam manifestar consentimento para participar da brincadeira e as que não estavam dispostas a fazer parte do festejo trancavam-se em casa e não ousavam sair à janela como informa Debret em Viagem pitoresca e histórica ao Brasil. Isto nos revela algo a mais sobre o entrudo: não era uma loucura que acometia todos e em que não se respeitavam certas regras. Sobre esse ponto, o relato de Jean-Baptiste Debret (1949, tomo 1, p. 221) é valioso. De acordo com ele, as pessoas "correm às janelas e alegremente solicitam, de longe e com gestos, 
licença para começar; ao mais ligeiro assentimento alguns limões trocados com habilidade e pontaria dão o sinal do ataque geral” (grifo meu).

A esse respeito há ainda a informação registrada por Robert Walsh (s/d, p. 175) de que o entrudo se transformara em ocasião de pancadas e feridas graves, porque frequentemente era praticado "contra a vontade dos indivíduos". Esse fato, ao nos colocar diante do inverso da situação, em sua lógica contrária assegura a existência de certo consentimento por parte dos envolvidos.

Por ser considerada festa generalizada, da qual toda a comunidade deveria participar, não era de estranhar que nos momentos de grande euforia esse detalhe fosse esquecido nem o fato de que havia mais espectadores do festejo do que participantes. Esse relato remete a mais uma questão acerca da festa: seu excesso e sua violência. A festa é normalmente concebida como momento de confraternização e de comunhão entre os indivíduos. E é; não resta dúvida de que se trata de momento privilegiado de manutenção e renovação dos laços de sociabilidade de uma comunidade. Entretanto, por ser marcado pela euforia, pela expansão das emoções, pela conjugação de significados de mundo e por criar espaço que promove estímulos e reações afetivas, gera tanto sentimentos de comunhão quanto de rivalidades.

$\mathrm{Na}$ festa convivem os dois lados de uma mesma moeda; por um lado, a harmonia e a concordância, e, por outro, os excessos e os tumultos. Apesar de todo o esforço empreendido para se manter sob controle, para se evitarem excessos, festa e violência não são desconhecidos, menos ainda indiferentes. De um momento para o outro, o que era um feliz momento de confraternização e brincadeira, transforma-se em violência e desregramento.

Segundo Thomas Ewbank (1979, p. 83), tanto homens quanto mulheres eram peritos em acalmar "uma vítima" após o ataque, fazendo-a abandonar sua atitude de reação e, ao se acalmar, perceber que isso fazia parte do jogo. E quanto mais divertida a brincadeira ficava, por poder-se rir da pessoa, tanto mais próxima da violência também.

As práticas mais visíveis e as mais disseminadas dos festejos de entrudo são, sem dúvida, aquelas envolvendo aspersões de água, ovos, farinha e pós diversos, e as brincadeiras com limões de cheiro. Durante o entrudo, no entanto, realizavam-se também trotes, isto é, peças em pessoas conhecidas. A ação que impelia as pessoas a fazer outras de "tontas" era o riso. Vê-las praticarem atividades ridículas era extremamente divertido, sendo importante fazer a "vítima", por desconhecimento do que fazia, receber o escárnio e a chacota de outros. A injúria aplicada não era física, mas moral.

Thomas Ewbank relata um desses "trotes" durante sua estada no Rio de Janeiro: uma pessoa de boa fé é mandada tratar do que imagina ser um assunto confidencial de grande importância para seu amigo - tomar dinheiro emprestado, por exemplo. A carta que leva diz em síntese: "Envie o tolo para o Sr. B. e peçaIhe para enviá-lo a outro com o mesmo pedido!" (p. 83).

Os trotes eram um tipo de brincadeira satírica, cujo sentido parece ser o de fazer incorporar ou fazer sentir-se incorporado à comunidade determinado indivíduo, partici- 
pante da brincadeira. É uma brincadeira jocosa, maneira de ridicularizar alguém que, ao ignorar o que se passa, se torna motivo de riso. Envolvia uma rede de pessoas da comunidade que, através de pacto e cumplicidade, aceitam participar da brincadeira e fazer de tolo o escolhido. Pessoas conhecidas, que mantêm laços de parentesco ou de amizade, se "injuriam" e riem uns dos outros.

Também os teatros podiam servir de espaço para o desenrolar dos jogos de entrudo. No Rio de Janeiro, permaneciam abertos e, a exemplo do que acontecia durante o dia pelas ruas, era também lugar para arremessos de projéteis (limões de cheiro) e água. De acordo com Robert Walsh (s/d, p. 175), as brincadeiras ocorriam preferencialmente dos camarotes para a plateia, seguindo a regra, como das sacadas para a rua. $\mathrm{O}$ destino dos teatros, quando construídos, não era certamente os jogos de entrudo, mas a capacidade de improvisação das pessoas fazia com que também esse ambiente se tornasse um dos espaços utilizados para festejarem. $\mathrm{O}$ acontecimento da festa nos teatros consistia também, provavelmente, em maneira de tentar controlar o desenvolvimento dos festejos, procurando eliminar os tumultos, mais fáceis de ocorrer nas ruas, cujo espaço era muito maior.

Vê-se assim que a prática do entrudo era disseminada por toda a sociedade brasileira, diferindo apenas com relação à dinâmica dos grupos no conjunto da esfera social. Era praticado por todos os grupos sociais, dos mais abastados aos mais pobres, com sentidos e nuanças diferentes. $O$ entrudo revela-se momento especial da vida cultural da sociedade brasileira do século XIX. Apesar das constantes proibições feitas a esse festejo durante todo o século XIX, ele será folguedo bastante disseminado, alegre e muito popular no Brasil; para sua imagem e informações a seu respeito foram preciosos os relatos dos viajantes que para cá se dirigiram, por motivos diversos, e registraram em detalhes elementos do universo cultural brasileiro.

\section{REFERÊNCIAS BIBLIOGRÁFICAS}

BAKHTIN, Mikhail. A cultura popular na Idade Média e no Renascimento. São Paulo: Hucitec, 1987.

BELUZZO, Ana Maria. A propósito d'O Brasil dos Viajantes. Revista USP, (30):8-19, São Paulo, jun./ago. 1996.

BINZER, Ina von. Alegrias e tristezas de uma educadora alemã no Brasil. São Paulo: Ed. Anhembi Ltda, 1956.

CARLOS, Ana Fani Alessandri. O lugar no/do mundo. São Paulo: Hucitec, 1996.

CUNHA, Maria Clementina Pereira. "Você me conhece?" Significados do carnaval na Belle Époque carioca. Projeto História, n.13, São Paulo, jun. 1996.

DEBRET, Jean-Baptiste. Viagem pitoresca e histórica ao Brasil. Trad. e notas Sérgio Milliet. 2. edição, Tomo I [v. I e II]. São Paulo: Livraria Martins Editora, 1949.

DENIS, Ferdinand. O Brasil [1816-1831]. Belo Horizonte/São Paulo: Itatiaia/Edusp, 1978.

EWBANK, Thomas. A vida no Brasil [1845-1846]. Belo Horizonte/São Paulo: Itatiaia/Edusp, 1979. 
FLETCHER, James Cooley; KIDDER, Daniel P. O Brasil e os brasileiros. São Paulo/Rio de Janeiro/Porto Alegre: Nacional, 1941.

GUIMARÃES, Manoel Luiz Salgado. História e natureza em Von Martius: esquadrinhando o Brasil para construir a nação. História, Ciências, Saúde - Manguinhos, vol. VII (2), 389-410, jul.-out. 2000.

HEERS, Jacques. Festas de loucos e carnavais. Lisboa: Dom Quixote, 1987.

KIDDER, Daniel P. Reminiscências de Viagens e Permanências no Brasil (Rio de Janeiro e Província de São Paulo), vol. III. São Paulo: Livraria Martins Ed., 1951.

KOSTER, Henry. Viagens ao Nordeste do Brasil. São Paulo: Companhia Editora Nacional, 1972.

LEITE, Ilka Boaventura. Antropologia da viagem - escravos e libertos em Minas Gerais no século XIX. Belo Horizonte: Editora UFMG, 1996.

LEITE, Míriam L. Moreira. Livros de viagem (1803-1900). Rio de Janeiro: Editora UFRJ, 1997.

MAWE, John. Viagens ao interior do Brasil [1807-1811]. Belo Horizonte/São Paulo: Itatiaia/ Edusp, 1978.

MORAES, Eneida de. História do carnaval carioca. Rio de Janeiro: Civilização Brasileira, 1958.

MORAES FILHO, Mello. Festas e tradições populares no Brasil. Belo Horizonte/São Paulo: Itatiaia/Edusp, 1978.

PRATT, Mary Louise. Os olhos do império, relatos de viagem e transculturação. Bauru: Edusc, 1999.

QUEIROZ, Maria Isaura Pereira de. A ordem carnavalesca. Tempo social; revista de sociologia da USP, 6 (1-2): 27-45, São Paulo, 1994.

. Carnaval brasileiro: da origem ao símbolo nacional. Ciência e Cultura, (39) 8, p. 717-729, São Paulo, 1987.

SCHWARCZ, Lilia Moritz. Viajantes em meio ao império das festas. Seminário Festas: Cultura e Sociabilidade na América Portuguesa. São Paulo: USP/FFLCH, 06-11 de set. 1999.

SILVA, Antonio de Morais. Diccionario da Lingua Portugueza. Recompilado dos vocabularios impressos até agora, e nesta segunda edição novamente emendado e muito acrescentado. Lisboa: Typographia Lacerdina, 1813.

WALSH, Robert. Notícias do Brasil [1828-1829].Belo Horizonte/São Paulo: Itatiaia/Edusp, s/d.

Patrícia Vargas Lopes de Araujo é doutora em História pela Universidade Estadual de Campinas e professora adjunta do Departamento de História da Universidade Federal de Viçosa, MG. 